\title{
Ecology and traits of plant species that compete with boreal and temperate forest conifers: An overview of available information and its use in forest management in Canada
}

\author{
by F. Wayne Bell ${ }^{1,2}$, Maureen Kershaw ${ }^{3}$, Isabelle Aubin ${ }^{4}$, \\ Nelson Thiffault ${ }^{5}$, Jennifer Dacosta ${ }^{1}$ and Alan Wiensczyk ${ }^{6}$
}

\begin{abstract}
In boreal and temperate forests in Canada, at least 71 plant species, including trees, shrubs, herbs, grasses, and ferns, have the potential to significantly reduce the growth of conifer regeneration. A thorough understanding of the autecology of these plants-their response to their environment-can help resource managers to improve their approaches to vegetation management, thereby maximizing crop tree growth and survival. In this paper, we highlight key sources of information about the autecology of the major species that compete with forest conifers, including books and field guides, journal series, Web sites, and plant trait databases. We suggest ways that this information can be applied in resource management, recommend approaches for maintaining and updating this information, and underline the needs for developing a single, consolidated, comprehensive source of such information for use by resource managers and researchers. Information gaps are also briefly discussed.
\end{abstract}

Key words: plant traits, life history traits, forest management, vegetation management, boreal forests, temperate forests

\begin{abstract}
RÉSUMÉ
Dans les forêts boréales et tempérées du Canada, au moins 71 espèces végétales, incluant des arbres, des arbustes, des herbacées, des graminées et des fougères, ont le potentiel de réduire significativement la croissance de la régénération de conifères. Une compréhension approfondie de leur autécologie-i.e. leurs réponses à l'environnement-peut aider les aménagistes et les sylviculteurs à améliorer leurs approches en contrôle de la végétation, et ainsi, à maximiser la croissance et la survie des espèces désirées. Dans cet article, nous identifions des sources d'information clés sur l’autécologie des principales espèces qui entrent en compétition avec les conifères, incluant des livres, des guides terrain, des séries d’articles, des sites Internet et des bases de données sur les traits fonctionnels des plantes. Nous suggérons des manières d'utiliser ces informations dans l'aménagement forestier, et recommandons des pistes pour en assurer la mise à jour. Nous soulignons également le besoin de développer une source unique, consolidée et exhaustive pour ces informations, qui pourra être utilisée par les aménagistes et les chercheurs. Finalement, nous discutons brièvement des besoins supplémentaires en informations.
\end{abstract}

Mots-clés : caractéristiques des plantes, traits fonctionnels, aménagement forestier, gestion de la végétation concurrente, forêts boréales, forêts tempérées

\section{Introduction}

In Canada, competitive vegetation establishes rapidly on newly disturbed sites, often at the expense of the short-term survival and growth of crop trees, and particularly conifers (Wagner et al. 2001). Resource managers' views about this competitive vegetation continue to evolve. When focused on managing forests primarily for timber production, they viewed controlling competitive vegetation as an essential silvicultural practice that ensures an environment favourable to the survival and growth of conifer plantations established in temperate and boreal forests (Walstad and Kuch 1987, Wagner 1994). However, as they entered an era of more holistic ecosystem management (Christensen et al. 1996, Chapin et al.
2002, Burton et al. 2003), understanding the roles of competing vegetation in ecosystem function and developing management strategies that effectively address the tradeoffs between the benefits and the costs of competing vegetation became even more essential for effective silviculture (Simard and Durall 2004; Nilsson and Wardle 2005; Gilliam 2007; S. Haeussler, UBC, personal communication, 2011). This required not only a shift in thinking, but also new approaches and a better understanding of species' autecology.

Autecology is the branch of ecology dealing with the study of the responses and adaptations of individual species or populations to their environment (Barbour et al. 1987). Most of the principal competitive species in boreal and temperate

\footnotetext{
${ }^{1}$ Ontario Forest Research Institute, Ontario Ministry of Natural Resources, 1235 Queen Street East, Sault Ste. Marie, Ontario P6A 2E5.

${ }^{2}$ Corresponding author. E-mail: wayne.bell@ontario.ca

${ }^{3}$ Faculty of Natural Resources Management, Lakehead University, Suite 202A, 1294 Balmoral St., Thunder Bay, Ontario P7B $5 Z 5$.

${ }^{4}$ Great Lakes Forestry Centre, Natural Resources Canada, 1219 Queen St. East, Sault Ste. Marie, Ontario P6A 2E5.

${ }^{5}$ Direction de la recherche forestière, Ministère des Ressources naturelles et de la Faune du Québec, 2700 Einstein, Québec, Québec G1P 3W8, and Associate Member, Centre d'étude de la forêt

${ }^{6}$ FORREX Forum for Research and Extension in Natural Resources, 400-1488 4th Ave, Prince George, British Columbia V2L 4 Y2.
} 
forests are perennial plants that are highly adapted for rapid establishment and growth following a disturbance. Collectively, the set of characteristics (such as reproductive strategies that ensure regrowth or physiological adaptations to sunlight, heat, shade, and drought) that enable plants to respond to changes in their environment, are referred to as species' autecological traits. Understanding these traits may enable forest managers to develop more effective vegetation management strategies to maximize crop tree survival and growth. However, information about the autecological traits of Canadian boreal and temperate forest plant species is scattered in a plethora of journal publications, unpublished file reports, and online sources. With the introduction of sustainable forest management certification systems, which require clear documentation and increased accountability, consolidating the reliable information and making it more readily retrievable has become even more critical.

In this paper, we provide resource managers with (i) a list of key species that have potential to negatively affect the growth of boreal and temperate forest conifers, (ii) suggestions about how to apply plant ecology information (iii), an introduction to the primary sources of information (iv), an overview of available information, and (v) insight to future developments in this topical area. We believe that this information will assist resource managers to achieve their vegetation management, as well as other forest management objectives, which may range, for example, from promoting species that enhance wildlife habitat to controlling erosion, reducing insect or disease problems, and increasing opportunities for non-timber forest products.

\section{Which Plants Have Potential to Negatively Affect the Growth of Boreal and Temperate Forest Conifers?}

The term competition has been defined in many ways (Connell 1980, Booth et al. 2003, Radosevich et al. 2007), depending on the context in which it is used and the degree of emphasis on the mechanism or outcome of the interaction. In our current context, a definition given by Begon et al. (1996) is appropriate: competition is "an interaction between individuals, brought about by a shared requirement for a resource in limited supply, leading to a reduction in the survivorship, growth and/or reproduction of at least some of the competing individuals concerned." In addition to competing for resources, several species interfere with the survival and growth of coniferous crop trees by acting as secondary hosts for rusts and other pests (e.g., see Mihail et al. 2002), by causing physical damage, or via allelopathy (Rice 1984). "Compet- ing species" may also improve conifer growth and survival by enhancing the recycling or fixing of nitrogen, ameliorating soil or air temperatures, and/or creating conditions less favourable to pests such as white pine weevil (Table 1). Competitive interactions comprise a complex balance of positive and negative exchanges among individuals (Brooker et al. 2008). These can be direct or indirect and more than one process may occur simultaneously between competing individuals, for example, both competition for light (negative effect) and increased nutrient cycling (positive effect) may occur. Thorough discussions about these interactions and their effects are available (see Booth et al. 2003, Radosevich et al. 2007, Brooker et al. 2008).

A list of species known or presumed to negatively affect the growth of boreal and temperate conifers and a brief summary of their key traits are provided in Table 2 . This overview illustrates that an array of plants of varying growth forms can be considered significant competitors for conifers. Of these 71 species, 44 are shrubs, 10 are forbs, 8 are trees, 4 are grasses, 4 are ferns, and 1 is a sedge. From this list it is also evident that competition for light ( 43 species) is deemed more important or common than competition for moisture (34 species) and nutrients (27 species). In absolute terms, shrub species are the most abundant in each of the categories. All of the trees as well as some of the shrub (27), forb (4), fern (3), and grass (1) species can attain sufficient height and cover to significantly compete for light with boreal conifers. In relative terms, competition for soil water is mostly associated with grass species (three of four species), but some trees, shrubs, and herbaceous species also affect this resource. Most trees are also considered significant competitors for soil nutrients, and several shrub and herbaceous species (see Table 2 for references).

\section{How Can Resource Managers Apply Plant Autecol- ogy Information?}

Whether one is developing silvicultural strategies or attempting to understand the effects of silviculture on plant communities, familiarity with the autecological characteristics of plant species is essential (Wagner and Zasada 1991). Table 3 presents several questions related to the autecology of competitor species that resource managers may wish to consider before implementing silvicultural treatments.

Each plant species will respond differently to disturbances, such as mechanical, thermal, cultural, and chemical treatments (see Wiensczyk et al. 2011, this issue), due to differences in their life history characteristics, regeneration strategies, and physiology. The ability of a plant species to evade,

Table 1. Effects of non-crop vegetation on crop trees (adapted from Booth et al. 2003, Radosevich et al. 2007)

\section{Negative}

- Compete for site resources (e.g., light, moisture, nutrients, growing space)

- Cause allelopathic interactions

- Create sod/litter (restricts seed germination and seedling development, and inhibits soil warming)

- Cause physical damage (e.g., snow press, smothering, whipping)

- Provide habitat for damaging insects and small mammals

- Act as alternate host for diseases

\section{Positive}

- Moderate air and soil temperature extremes, reduce the vapour pressure deficit

- Protect from insects (e.g., white pine weevil)

- Capture, store and share nutrients, nitrogen fixation

- Reduce physical damage from wind

- Add organic matter to surface soils that may provide medium for soil microbes and may improve nutrient availability 


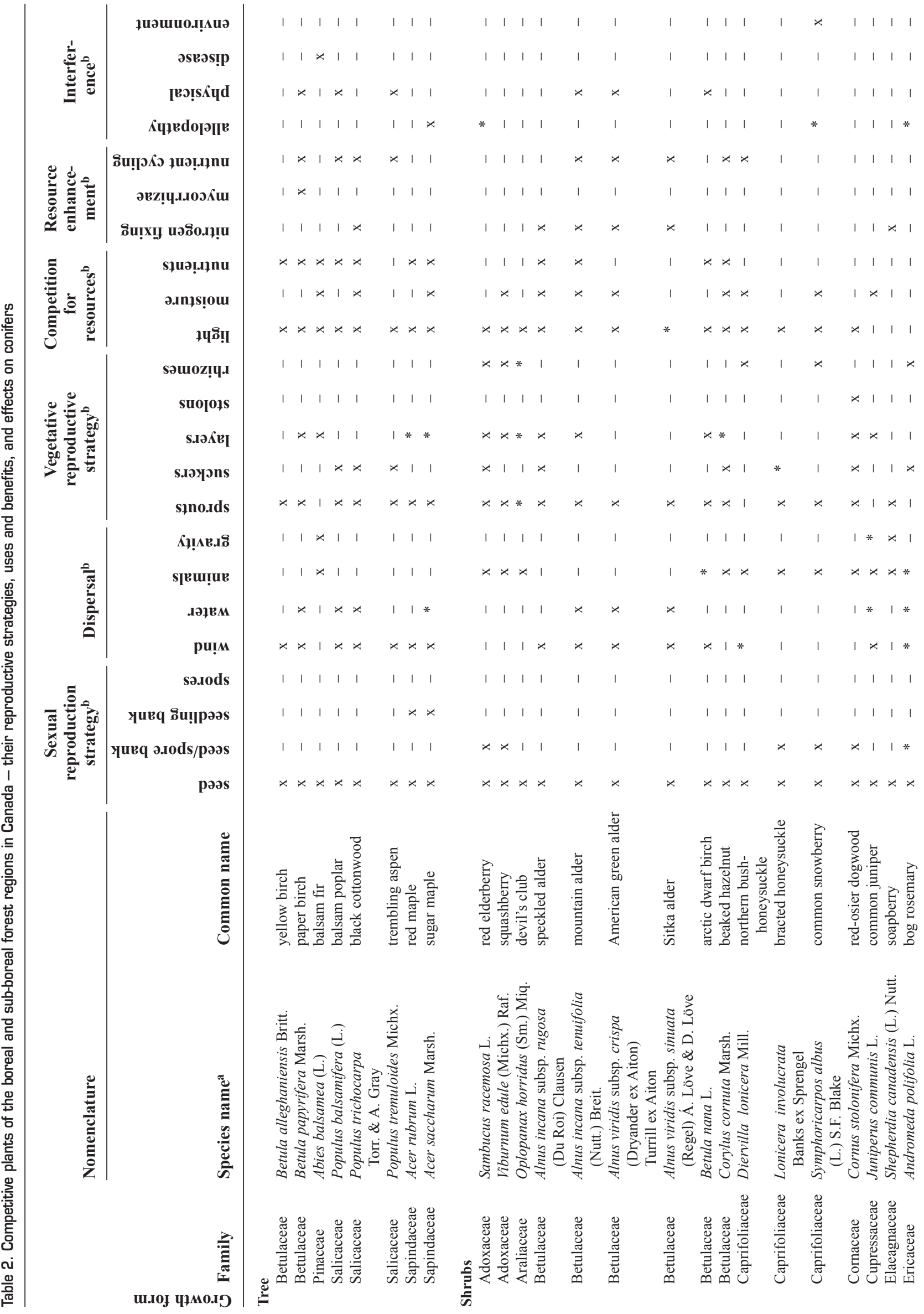




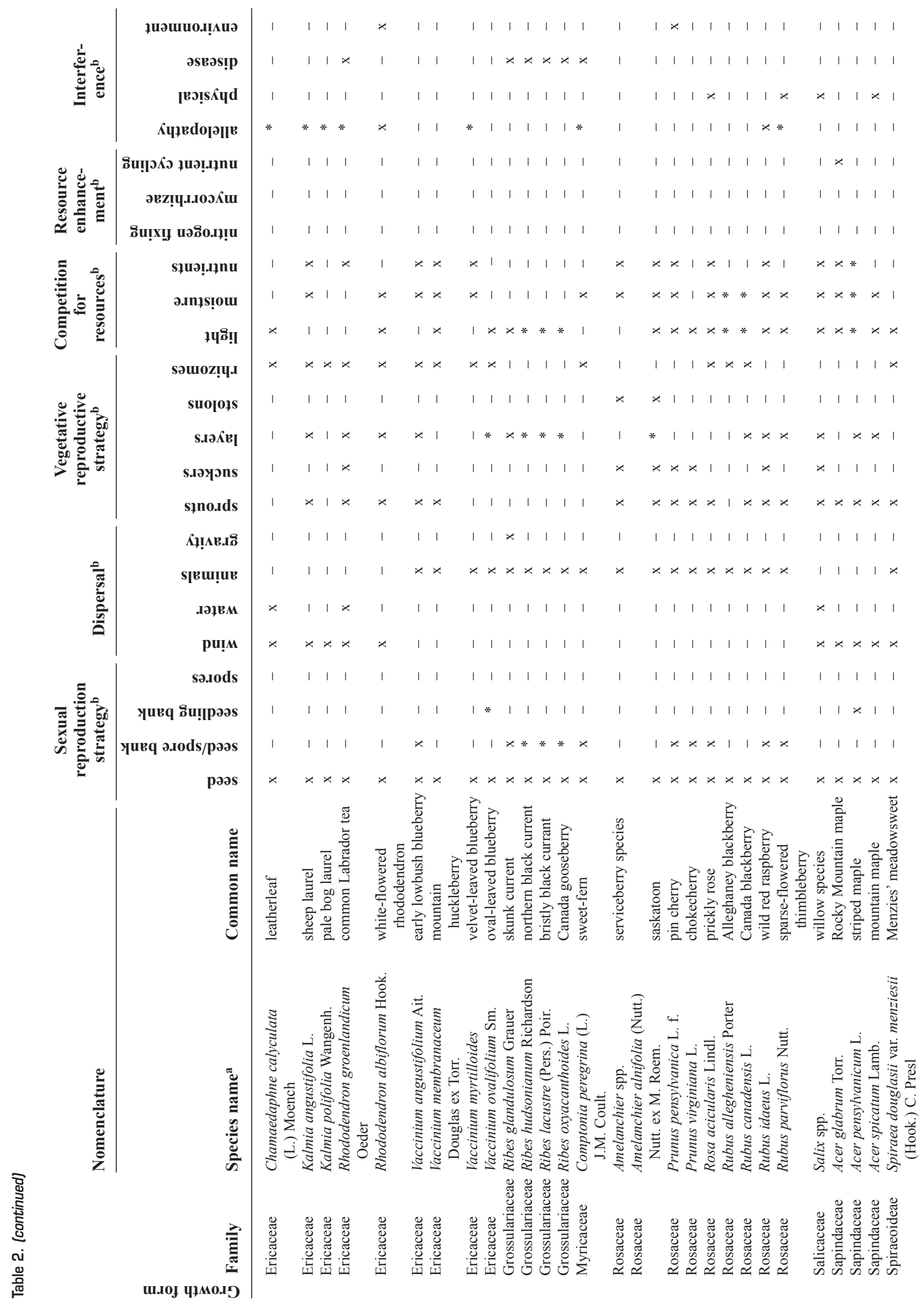




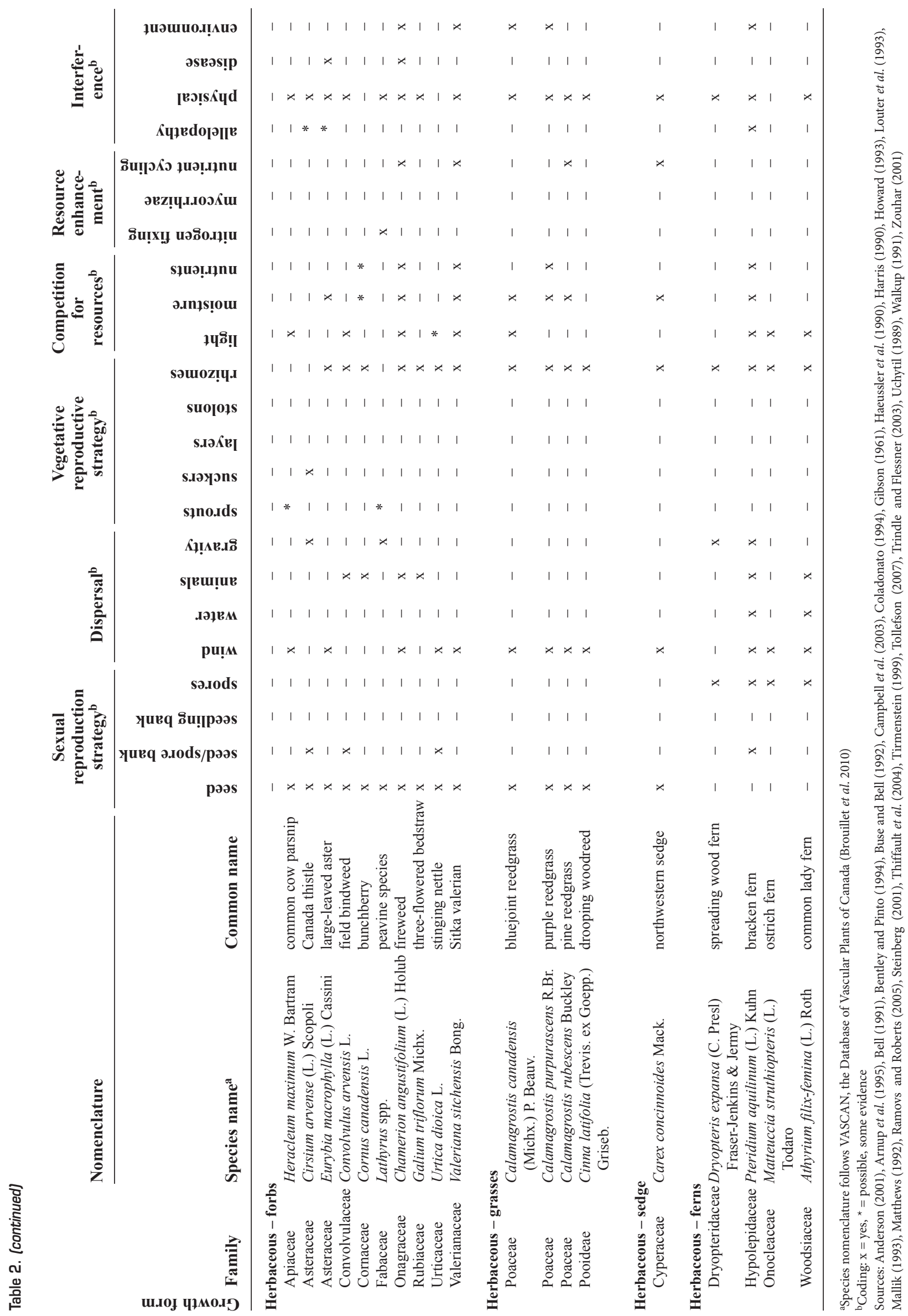




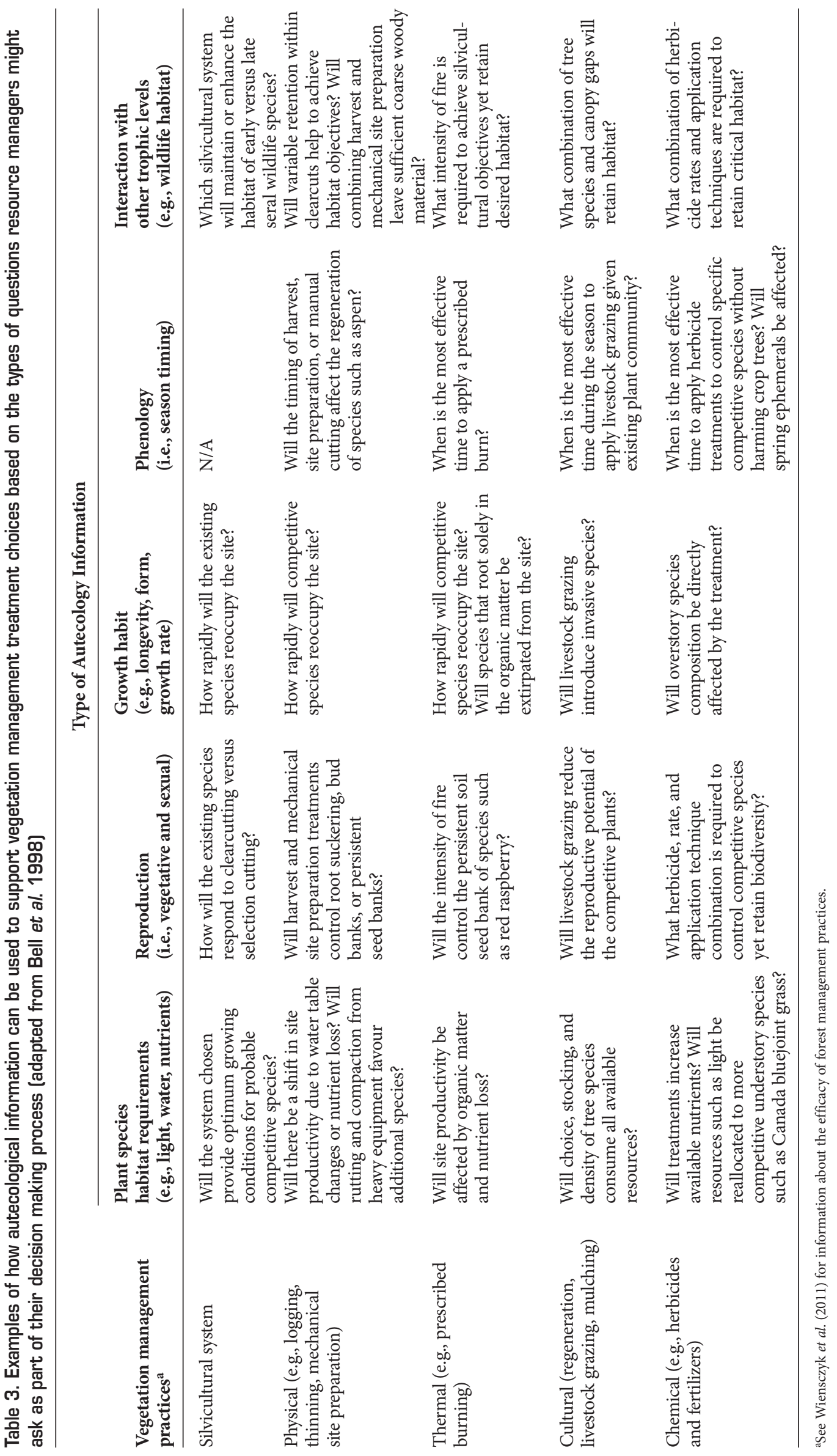


escape, or resist human-caused disturbance will ultimately depend on the traits it has developed to respond to various natural disturbances such as fire, browsing, insects, and disease (Bell et al. 1998).

Additional considerations for resource managers include the temporal nature of competition-its likeliness to persistand the ability of individual species to pre-empt resources. These are captured in the dominance potential concept proposed by Newton (1973): "Dominance potential (DP) ... is the summation of all features of a species relating to its ability to assume dominance over a specific length of time in a limited system." For a given site, a species with initial high dominance potential will tend to replace or suppress a species with lower DP unless action is taken to suppress the species with high DP or the species with lower DP is established first. A species with high "long-term" DP (e.g., trees) may prevail and eventually displace a species with high "short-term" DP (e.g., brush competitors).

\section{What Are The Primary Sources of Plant Autecology Information?}

Information about the autecology of plants is available in books, field guides, and journal series, as well as on Web sites and in plant trait databases, each of which are described in more detail below. In addition to this published and/or documented information, resource managers can apply local knowledge about species autecology. The literature is far from complete and may be inaccurate for local areas. Thus, local expert knowledge may be useful to supplement documented information.

\section{Books and field guides}

The first autecology guide was published in Germany (Kirchner et al. 1908-1936, cited in Klimešová and Klimeš 2008). This ambitious series remains incomplete but includes more than 300 species, which is more than what is included in most subsequent series. More recently, the characteristics of about 200 forest tree species and varieties are described in Silvics of North America (Burns and Honkala 1990). Most of the species included in this volume are native to North America, but a few are introduced and naturalized. Information on habitat, life history, and genetics is given for 15 genera, 63 species, and 20 varieties of conifers, and for 58 genera, 128 species, and 6 varieties of hardwoods. These include all of the trees presently considered commercially important in Canada.

The Woody Plant Seed Manual is a comprehensive handbook on the seeds of trees and shrubs of North America. Earlier versions include Woody-Plant Seed Manual (USDA 1948) with 420 taxa in 140 genera, and Seeds of Woody Plants in the United States (Schopmeyer 1974) with approximately 800 taxa in 188 genera. The current version contains almost 1,300 taxa in 230 genera (Bonner and Karrfalt 2008).

Since 1986, books and field guides that focus on plants that compete with boreal and temperate forest conifers have been published to assist resource managers in designing vegetation management strategies in British Columbia (Haeussler and Coates 1986, Coates et al. 1990, Haeussler et al. 1990), Ontario (Sims et al. 1990, Bell 1991, Buse and Bell 1992, Louter et al. 1993, Bentley and Pinto 1994, Arnup et al. 1995), and Quebec (Jobidon 1995). In total, these publications describe 153 species: 8 conifer, 85 deciduous tree and shrub, 27 herb, 17 graminoid, 3 fern, 3 lichen, 3 moss, and 7 sphagnum species.

\section{Journal series}

In Great Britain, the Biological Flora of the British Isles series was started in 1941 and by the end of 1997 included more than 250 species. The most extensive biological floras following the British concept are published for the Moscow Region (Rabotnov 1974, cited in Klimešová and Klimeš 2008) and for the weeds of Canada-The Biology of Canadian Weeds (Cavers and Mulligan 1972); the latter includes about 144 species. A biological flora of Central Europe also contains relevant information (Poschlod et al. 1996). These journal series contain a wealth of botanical and scientific detail that is missing from the more practically oriented field guides described above.

\section{Web sites}

The internet is rich with information but much time and patience is required to ferret out what is reliable and relevant. Several useful and reliable online databases (Table 4) provide information about:

- Phylogeny, nomenclature, and/or rarity status - Canadensys and VASCAN, Flora of North America (FNA), FLORA Ontario - Integrated Botanical Information System (FOIBIS), and Northern Ontario Plant Database (NOPD)

- Species ecology - Fire Effects Information System (FEIS), USDA Plant Guides, and North European and Baltic Network on Invasive Alien Species (NOBANIS)

- Species distributions - plant hardiness

\section{Plant Trait Databases}

A trait is a plant characteristic, such as seed size, which can be measured at the scale of an individual species and has an effect on the species' fitness and/or adaptation to an environmental constraint (Violle et al. 2007). Classifying species by shared biological characteristics, rather than their phylogeny, is increasingly recognized as a tool that is useful to identify common functional response groups among taxa (Grime 1988, Lavorel et al. 1997, Díaz and Cabido 2001). This approach is useful to resource managers because groups of plants with similar traits are likely to respond similarly to, for example, disturbance, and thus effective strategies can be developed for these groups rather than for each species individually. However, a thorough knowledge of species autecology is absolutely necessary to further develop this approach.

Since 1998, expansion of the development and use of plant trait databases (Table 5) has been rapid. Trait databases are increasingly used by the scientific community to model ecosystem responses to a variety of human-induced changes (e.g., see recent papers in the journals Ecology, Nature, and Science). They may also be useful in applied science (e.g., Aubin et al. 2008), as well as for assessing risk and developing silviculture guides (e.g., Bell et al. 1998).

Most of the existing databases are populated with information about European plant species (as per Table 5). This information is of some value to Canadian resource managers since some European species are invasive in Canadian forests. As well, databases are now being populated with what is known about Canadian species. These include TOPIQ (Aubin et al. 
Table 4. Online databases that provide information about the phylogeny, nomenclature, rarity status and/or distribution of competitive species

\begin{tabular}{|c|c|}
\hline Web site & Description \\
\hline Canadensys & $\begin{array}{l}\text { Canadensys was created and maintained by The Montreal Biodiversity Centre. } \\
\text { Canadensys was designed to share specimen information held by Canadian univer- } \\
\text { sity-based biological collections and link this information via a network of distributed } \\
\text { databases, compatible with other biodiversity information networks such as the } \\
\text { Canadian Biodiversity Information Facility (CBIF) and the Global Biodiversity Infor- } \\
\text { mation Facility (GBIF). Initially the network will focus on data from three of the } \\
\text { most diverse and ecologically and economically important groups of organisms } \\
\text { including plants. }\end{array}$ \\
\hline VASCAN & $\begin{array}{l}\text { The Database of Canadian Vascular Plants (VASCAN) hosted by the Canadensys } \\
\text { Web site provide an up-to-date, documented source of the names of vascular plants } \\
\text { in Canada }\end{array}$ \\
\hline FEIS & $\begin{array}{l}\text { Fire Effects Information System (FEIS) database was developed by the United States } \\
\text { Department of Agriculture. FEIS contains literature reviews about the effects of fire } \\
\text { for about } 900 \text { plant species, many of which compete with boreal and temperate forest } \\
\text { conifers. Background information on taxonomy, distribution, basic biology, and ecol- } \\
\text { ogy of each species are included. }\end{array}$ \\
\hline
\end{tabular}

FOIBIS FLORA Ontario - Integrated Botanical Information System (FOIBIS) was developed by the University of Guelph. FOIBIS provides information about phytogeography, rarity, and nomenclature for over 5000 plant species, including vascular plants, bryophytes and lichens that grow in Ontario. It includes native species as well as some ornamentals, weeds, invasive aliens, arctic disjuncts, and agricultural plants.

Forestis Forestis is a virtual herbarium hosted at Universite Laval. The site is based on a powerful search engine that gathers hundreds of documents on any given species, each time it is used. The sources notably include digitalized herbarium and fresh plant specimens and scans from major North American and foreign flora collections.

FNA Flora of North America (FNA) presents information on the names, taxonomic relationships, continent-wide distributions, and morphological characteristics of all native and naturalized plants that occur in North America north of Mexico.

NOBANIS North European and Baltic Network on Invasive Alien Species (NOBANIS) is a gateway to information on alien and invasive species in North and Central Europe. NOBANIS provides fact sheets on many of the most invasive alien species in the region and include several species introduced from North America. These fact sheets include species distributions and recommended preventive, eradication, and control measures.

NOPD Northern Ontario Plant Database (NOPD) was developed by Algoma University. NOPD provides access to over 55000 herbarium specimens in northern Ontario educational and government institutions. NOPD also provides descriptions of many northern Ontario plant species to assist foresters, students, and interested members of the public in identifying local flora.

Plant Plant hardiness was developed by the Canadian Forest Service. It presents range maps hardiness for individual species of trees, shrubs, and perennial flowers that are based on climatic profiles for each plant using continent-wide climate models, supplemented by actual observations of plant occurrences

USDA Plant USDA Plants provides facts sheets and plant guides for many species that occur in Guide Canada. Fact sheets provide brief descriptions of a plant and its uses, and offer cultural recommendations, such as providing habitat for wildlife. Plant guides emphasize a particular aspect of a plant's biology and typically reference source documents. These products can be used with other tools available through PLANTS, especially VegSpec. VegSpec lets user select plants based on geography, a plant's adaptability to soils and climate, an intended conservation use, and other variables. After generating a shortlist using VegSpec, the fact sheets or plant guides are useful to learn more about each plant and its suitability for a specific purpose.
Source

http://www.canadensys.net/

[Accessed Jan. 12, 2010]

http://data.canadensys.net/vascan/ search/

[Accessed Jan. 12, 2010]

http://data.canadensys.net/vascan/ [Accessed Dec. 7, 2011]

http://www.fs.fed.us/database/feis/ index [Accessed Oct. 9, 2010]

Newmaster and Subramanyam (2005)

http://www.uoguelph.ca/foibis/

[Accessed Oct. 27, 2010]

http://forestis.rsvs.ulaval.ca/ [Accessed Nov. 4, 2010]

http://forestis.rsvs.ulaval.ca/ [Accessed Nov. 4, 2010]

http://www.nobanis.org/default.asp [Accessed Oct. 28, 2010]

http://www.northernontarioflora.ca/ [Accessed Oct. 28, 2010]

McKenney et al. (2001)

http://planthardiness.gc.ca/ ph_technicaldetails.pl?lang=en [Accessed Oct. 11, 2011]

http://plants.usda.gov/ [Accessed Oct. 29, 2010] 
Table 5. Functional plant trait databases available or in development worldwide

\begin{tabular}{|c|c|c|}
\hline Name & Description & Source \\
\hline BIOFLOR & Includes 66 traits for approximately 3660 vascular plants in Germany & $\begin{array}{l}\text { Klotz et al. (2002) } \\
\text { www.ufz.de/bioflor/index.jsp }\end{array}$ \\
\hline BIOPOP & $\begin{array}{l}\text { Provides ecological and life history traits of the vascular plants species } \\
\text { of the Central European flora }\end{array}$ & $\begin{array}{l}\text { Poschlod et al. }(2000,2003) \\
\text { http://www.floraweb.de/ } \\
\text { proxy/en/index.php }\end{array}$ \\
\hline BROT & $\begin{array}{l}\text { Summarizes fire-related traits for } 859 \text { vascular plant species of the } \\
\text { Mediterranean Basin }\end{array}$ & $\begin{array}{l}\text { Paula and Pausas (2008), } \\
\text { Paula et al. (2009) } \\
\text { http://www.uv.es/jgpausas/ } \\
\text { brot/BROT_2008.11.txt }\end{array}$ \\
\hline CLO-PLA3 & $\begin{array}{l}\text { Outlines clonal growth and vegetative regeneration of vascular flora } \\
\text { of Central Europe. CLO-PLA3 partly overlaps with the LEDA }\end{array}$ & $\begin{array}{l}\text { Klimešová and Klimeš (2008) } \\
\text { http://clopla.butbn.cas.cz/ }\end{array}$ \\
\hline EIBER & $\begin{array}{l}\text { Indicates resprouting capacity }(\mathrm{R}) \text { and the propagule persistence }(\mathrm{P}) \\
\text { of woody species growing in the eastern Iberian Peninsula } \\
\text { (Mediterranean Basin) }\end{array}$ & $\begin{array}{l}\text { Pausas et al. (2004), } \\
\text { Pausas and Verdu (2005) } \\
\text { Not available online }\end{array}$ \\
\hline GLOPNET & $\begin{array}{l}\text { Includes chemical, structural, and physiological traits of leaves for } \\
\text { several species world-wide }\end{array}$ & Wright et al. (2004) \\
\hline LEDA & $\begin{array}{l}\text { Lists } 46 \text { life history traits for about 3,000 species of Northwest } \\
\text { European flora; Focuses on } 3 \text { key features of plant dynamics: persistence, } \\
\text { regeneration, and dispersal }\end{array}$ & $\begin{array}{l}\text { Knevel et al. (2003), } \\
\text { Kleyer et al. (2008) } \\
\text { http://www.butbn.cas.cz/klimes/ }\end{array}$ \\
\hline $\begin{array}{l}\text { SID (Seed } \\
\text { Information } \\
\text { Database) }\end{array}$ & $\begin{array}{l}\text { Includes taxon-based information on a range of seed biological } \\
\text { characteristics }\end{array}$ & $\begin{array}{l}\text { Royal Botanic Gardens Kew (2008) } \\
\text { Seed Information Database (SID). } \\
\text { Version 7.1. (May 2008) } \\
\text { http://data.kew.org/sid/ }\end{array}$ \\
\hline $\begin{array}{l}\text { TOPIQ (Traits of } \\
\text { Plants in Quebec) }\end{array}$ & $\begin{array}{l}\text { Includes } 650 \text { vascular plant species of Quebec and Ontario; } 41 \text { traits are } \\
\text { documented of which } 23 \text { are completed and validated }\end{array}$ & $\begin{array}{l}\text { Aubin et al. (2007) } \\
\text { Not available online }\end{array}$ \\
\hline TRY & $\begin{array}{l}\text { Is a global database of plant functional traits with }>100 \text { data contributors } \\
\text { and }>2500000 \text { trait records compiled }\end{array}$ & $\begin{array}{l}\text { http://www.try-db.org/index. } \\
\text { php?n=Main.HomePage }\end{array}$ \\
\hline
\end{tabular}

2007) and TRY (Table 5). Unfortunately, access to information in the trait databases is currently largely restricted to members. Resource managers can obtain information either by working with a database member or becoming a member. Membership is typically gained by submitting a predetermined number of observations (e.g., 500) to encourage those who collect plant trait information to both contribute and benefit from the database.

\section{What Information is Included in Autecology Guides and how is it Useful?}

Autecology guides published in Canada (i.e., Haeussler and Coates 1986, Haeussler et al. 1990, Bell 1991, Louter et al. 1993, Bentley and Pinto 1994, Jobidon 1995) provide information about species' nomenclature, growth habit, reproduction, phenology, ecophysiology, and response to disturbance.

\section{Nomenclature}

Plants are given different common names and even scientific names evolve over time. For example, fireweed, also called great willowherb or rosebay willow herb, is known by various scientific names, including Epilobium angustifolium, Chame- rion angustifolium and Chamaenerion angustifolium. This can make it difficult to find relevant information. The available autecology guides typically use regional nomenclature and, depending on when they were published, the scientific nomenclature used in these guides may no longer be preferred in published literature. An emerging approach is the use of DNA analysis to identify plant relationships, which is also influencing the evolution of naming conventions. If in doubt about a species name, resource managers can use online sources such as the Integrated Taxonomic Information System (ITIS; http://www.itis.gov/info.html), FOIBIS (http://www.uoguelph.ca/foibis/), or the Database of Vascular Plants of Canada (VASCAN) for confirmation (Table 4). VASCAN provides updated Canada-wide nomenclature and can be used as the standard reference (Brouillet et al. 2010; http://data.canadensys.net/vascan/).

\section{Description}

Autecology guides typically provide brief written descriptions and illustrations of stems, leaves, flowers, and fruits for selected species. These are not intended as comprehensive taxonomic descriptions. Since the morphology of a species 
may change across its distribution, we recommend that resource managers use local plant identification guides to identify plants with certainty.

\section{Distribution}

Distribution maps can be used as indicators of where competitive plants may occur. However, these maps are not always accurate due to, for example, to lack of knowledge and/or resolution of mapping. As well, existing models that predict plant migration may overestimate the speed at which plant distributions will change as the climate changes and detailed maps produced in the $20^{\text {th }}$ century may be rapidly outdated. Since the autecology guides are relatively static, resource managers are encouraged to visit the national plant hardiness-related web site (http://www.planthardiness.gc.ca/), which is more likely to provide updated information about potential distributions based on climate suitability.

\section{Habitat requirements}

Habitat requirements include the site and soil types where a species is likely to be found, and information about how it consumes light, water, and nutrients. Regional forest ecosystem classification (FEC) information linked to plants species, e.g., Klinka et al. (1989) and Beaudry et al. (1999, 2003) provide information for British Columbia, and Sims et al. (1990), Bell (1991), and Bentley and Pinto (1994) provide that for Ontario. Combined with some knowledge of plant resource requirements, resource managers can use this information to develop site-specific silvicultural practices to promote or retard the growth of selected species. With the addition of climatic tolerances, such as temperatures and precipitation, the effects of climate change on species distributions can be modelled (McKenney et al. 2001). At present, resource use and climatic tolerance for many understory species are poorly understood and are topics that require future research.

\section{Reproduction}

Knowledge of reproductive strategies can be used to predict species responses to disturbance. Plant species with high reproductive capabilities are more difficult to control and easier to promote than species with limited reproductive capabilities.

Almost all competitive plants reproduce both vegetatively and sexually. Sexual reproduction includes the current seed crop for seed-producing species as well as the seed bank for species (e.g., pin cherry, red raspberry) with seed that remain viable in the soil for extended periods. Vegetative reproduction strategies include regeneration from roots (suckering) and rhizomes as well as regeneration from shoots (root collar or lower stem sprouts), stolons, layering (Table 2), or by fragmentation. Although not included in Table 2, fragmentation is an important method of regeneration for balsam poplar (Populus balsamifera L.), some willows, lichens, and various other plants. Most plant species have more than one strategy; thus, their response to treatment will depend on the type and severity of disturbance (Wiensczyk et al. 2011) as well as other factors such as timing during the year or the plant's life stage.

Following a low-intensity disturbance, vegetative reproduction is generally more important in the rapid recovery of plant cover than sexual reproduction (Roberts 2004). For example, sprouting from suckers connected to parent plants with established food reserves and water supply (Zasada 1971) facilitates regrowth of site-adapted individuals regard- less of seed supply, dispersal, viability, or seedbed conditions.

Following a high-intensity disturbance, seed production (see Schopmeyer 1974, Young and Young 1992) will be important in the species colonization phase (Roberts 2004). Species that reach sexual maturity and produce large amounts of seed early in their life cycle have a competitive advantage over those that first produce seeds at older ages (Zasada 1988). Silvicultural disturbances can be timed according to knowledge of seed arrival, as many wind-borne seeds have limited viability and new seedlings cannot compete with established plants (Marks 1974).

Knowledge of seed longevity in the soil helps resource managers to understand and predict plant population dynamics and response to disturbances as well as to design effective vegetation management strategies (Wiensczyk et al. 2011). Following timber harvest, fire, or another major disturbance in a mature forest stand, infrequent species may become established from buried seeds and quickly dominate the pioneer vegetation community. Seeds buried in the organic layer and upper mineral soil (seed bank), some of which remain dormant in the soil for many years, germinate in response to increased light, soil temperature, or other changes following site disturbance (Conn and Farris 1987, Kramer and Johnson 1987). Seed bank species composition and seed densities will vary greatly from site to site (Kramer and Johnson 1987) and vegetation management strategies will need to be adjusted accordingly.

For comprehensive reviews of the sexual reproduction of plants, refer to Seeds of Woody Plants in North America (Young and Young 1992), Seed Ecophysiology of Temperature and Boreal Zone Forest Trees (Farmer 1997) and Seeds: Ecology, Biogeography, and Evolution of Dormancy and Germination (Baskin and Baskin 2001).

\section{Propagation}

Plant propagation is the multiplication of plants by both sexual and asexual means (Dirr 1990). An understanding of propagation techniques can be used in research and rehabilitation projects. Several of the existing autecology guides include information about seeding, vegetative propagation, micropropagation, and transplanting.

\section{Growth habit}

The growth habit of a plant determines its relative competitiveness in a forest community, and includes life cycle (e.g., annual, biennial, or perennial), life form (herb, shrub, or tree), longevity, and growth pattern. Annuals and biennials complete their life cycles after producing seeds in one and two years, respectively. With such a short life span, annuals and biennials rarely constitute a serious obstacle to conifer regeneration. They may, however, reduce height growth of and occasionally even smother (through snow load) small conifer seedlings (Bell et al. 1998). Perennials (trees, shrubs, and herbs that live for more than two years) may create greater competition through rapid spring growth from overwintered roots and shoots or rapid recovery following a disturbance. For instance, perennial grasses form thick mats that impede seedling establishment by creating an unsuitable seedbed, shading, and contributing to winter smothering (Bell 1991). Another example is the tall broad-leaved shrub mountain maple (Acer spicatum Lamb.) that persists through all stages of succession and can create a dense canopy after disturbance, 
drastically reducing the availability of light reaching the ground (Aubin et al. 2005). All species listed in Table 2 are perennials.

Growth patterns (e.g., stem height, clone size, rooting zone, and root grafting) also contribute to a plant's competitive status and influence how they respond to management treatments or disturbances. For example, the maximum height that a species can achieve will determine if it will be a competitor for only a few or many years. Root grafting enables subordinate plants to obtain nutrients from dominant plants and may also enable the transfer of herbicides from one individual to another.

\section{Phenology}

Phenology is the study of the timing of life-cycle events in relation to environmental cues. It includes the timing of growth events such as bud break, shoot elongation, bud set, flowering, seed set and fall, carbohydrate movement, leaf colouration and drop, frost hardening, and dormancy (Wagner and Zasada 1991). Timing of root development, for example, affects the uptake of moisture, nutrients, and soilactive herbicides (Bell et al. 1998).

Phenological information is essential to achieve maximum efficacy from vegetation management treatments, including prescribed fire (Noste et al. 1987), motor-manual cutting (Harrington 1984, Jobidon 1997, Bell et al. 1999) and herbicides (Bell et al. 2000, Bell and Pitt 2007). Most autecology guides provide information about shoot phenology (i.e., timing of leaf flush, radial expansion, and dormancy) and reproductive phenology (i.e., time of flowering, seed maturation and seed fall) that can be used, for example, to determine optimum treatment timing (see Bell and Pitt 2007).

\section{Interactions with other trophic levels}

Existing autecology guides provide some information about the relationship between animals and plants, with emphasis primarily on damaging effects (e.g., moose defoliation). In a study in Minnesota, Posner and Jordan (2002) concluded that browsing by moose reduced the height of shrubs competing with white spruce saplings, providing a release effect. Similarly, using exclosures to keep moose out of experimental plots on the island of Newfoundland, McLaren et al. (2009) reported that balsam fir outside the fenced plots where moose were free to browse on competing hardwoods were larger than those inside the enclosure where competition from hardwoods was not reduced.

Positive interactions between plants and animals (such as control of major pests) have received less attention. For example, in their comprehensive review of the relationships between spruce budworm and birds, Venier and Holmes (2010) concluded that birds influence budworm cycles at endemic population levels through predation of large larvae and pupae. Also, while bird predation is not the primary cause of budworm population variations, it may help to determine the mean level of oscillations (and by inference the amount of resultant damage)

\section{What Lies Ahead?}

During the 1990s, several regional autecology guides were prepared and distributed to resource managers in British Columbia, Ontario, and Quebec. These guides served their original purpose of providing resource managers with information about "weed species", but they are rapidly becoming outdated. Up-to-date information is needed for more than just species that were once considered weeds. Demand is growing for information about rare and invasive species and species other than trees that have commercial value or important roles in ecosystem function, such as nutrient or carbon cycling. Knowledge about the effects on forest species of changes in climate is also required. As well, additional information on the complex interactions among crop trees, their competitors, and organisms from other trophic levels is needed to provide resource managers with a more comprehensive understanding of ecosystem dynamics and how these are influenced by silvicultural treatments (Puettmann et al. 2008).

Given these demands, now is the time to aggregate the existing guides into a single, standardized, and current source that can be accessed by both resource managers and the scientific community. As well, an urgent need exists to incorporate the information into a user-friendly national database, such as Traits of Plants in Canada (TOPIC), and international trait databases such as TRY (Table 4). Once this happens, resource managers across Canada can look forward to easily accessible and comprehensive information about plant autecology for use in future resource management decision-making.

\section{Acknowledgements}

We are grateful to the Agricultural Research Institute of Ontario (ARIO) for sponsoring ongoing work on the autecology of forest plants, to the many individuals who provide information about the autecology of forest plants through their books, journal papers, Web sites, and plant trait databases and to Lisa Buse, Sybille Haeussler, Kandyd Szuba, Denise Tousignant, and Bob White for reviewing and commenting on earlier versions of this manuscript.

\section{References}

Anderson, M.D. 2001. Acer glabrum. In Fire Effects Information System. U.S. Department of Agriculture, Forest Service, Rocky Mountain Research Station, Fire Sciences Laboratory (Producer) [online]. Available at http://www.fs.fed.us/database/feis/ [Accessed October 27, 2010].

Arnup, R., B. Dowsley, L.J. Buse and F.W. Bell. 1995. Pocket guide to autecology of selected crop trees and competitor species in northeastern Ontario. Ont. Min. Nat. Resour., Northeast Sci. Technol. Devel., Timmins, ON. 134 p.

Aubin, I., S. Gachet, C. Messier and A. Bouchard. 2007. How resilient are northern hardwood forests to human disturbance? An evaluation using a plant functional group approach. Ecoscience 14(2): 259-271.

Aubin, I., C. Messier and A. Bouchard. 2008. Can plantations develop understory biological and physical attributes of natural forests? Biol. Conserv. 141(10): 2461-2476.

Aubin, I., C. Messier and D. Kneeshaw. 2005. Population structure and growth acclimation of mountain maple along a successional gradient in the southern boreal forest. Ecoscience 12(4): 540-548.

Barbour, M.G., J.H. Burk and W.D. Pitts. 1987. Terrestrial Ecology. The Benjamin/ Cummings Publ. Co. Inc., Menlo Park, CA. 634 p.

Baskin, C.C. and J.M. Baskin. 2001. Seeds: Ecology, Biogeography, and Evolution of Dormancy and Germination. Academic Press, San Diego, CA.

Beaudry, L., R. Coupé, C. Delong and J. Pojar. 1999. Plant indicator guide for northern British Columbia: Boreal, sub-Boreal, and subalpine biogeoclimatic zones (BWBS, SBS, SBPS, and northern ESSF). B.C. Min. For., For. Div. Serv. Br. Victoria, BC. 
Beaudry, L., R. Coupé, C. Delong and J. Pojar. 2003. Plant indicator guide for northern British Columbia: the northern portion of the MS and ICH biogeoclimatic zones. B.C. Min. For., Res. Br., Victoria, BC. B.C. Tech. Rep. 010.

Begon M., J.L. Harper and C.R. Townsend. 1996. Ecology: Individuals, Populations and Communities, $3^{\text {rd }}$ ed. Blackwell Publ., Oxford, UK. 1068 p.

Bell, F.W. 1991. Critical silvics of conifer crop species and selected competitive vegetation in northwestern Ontario. For. Can., Ont. Min. Nat. Resour., COFRDA Rep. 3310/NWOFTDU Tech. Rep.19. 177 p. Bell, F.W., W.C. Parker, R.G. White, D.R. Duckert and J.E. Elliot. 1998. Sec. 3.4.7: Autecology of associated plants. In A silvicultural guide for the Great Lakes - St. Lawrence conifer forest in Ontario. pp. 1-16. Ont. Min. Nat. Resour., Toronto, ON.

Bell, F.W. and D.G. Pitt. 2007. Seasonal susceptibility of boreal plants: Red raspberry phenology as a bioindicator of optimum withinseason timing of glyphosate applications. For. Chron. 83(5): 733-741. Bell, F.W., D.G. Pitt, A.U. Mallik and D.C. Hollstedt. 2000. Seasonal susceptibility of boreal plants to glyphosate. I. Blue-joint grass and black spruce. North. J. Appl. For. 17(4): 141-148.

Bell, F.W., D.G. Pitt, A.E. Morneault and S.M. Pickering. 1999. Response of immature trembling aspen to season and height of cut. North. J. Appl. For. 16(2): 108-114.

Bentley, C. and F. Pinto. 1994. Autecology of selected understory vegetation in central Ontario. Ont. Min. Nat. Resour., Cent. Reg. Sci. Technol. Unit, North Bay, ON. CRST Tech. Rep. \#31/VMAP Tech. Rep. \#93-08. 142 p.

Bonner, F.T. and R.P. Karrfalt (eds.). 2008. The Woody Plant Seed Manual. USDA For. Serv., Washington, DC. Agric. Handb. No. 727. $1223 \mathrm{p}$.

Booth, B.D., S.D. Murphy and C.J. Swanton. 2003. Weed Ecology in Natural and Agricultural Systems. CABI Publishing, Oxon, UK. $303 \mathrm{p}$.

Brooker, R.W. et al. 2008. Facilitation in plant communities: The past, the present, and the future. J. Ecol. 96(1): 18-34.

Brouillet, L., F. Coursol, M. Favreau and M. Anions (compilers). 2010+. VASCAN, the Database of Vascular Plants of Canada [online]. Available at http://data.canadensys.net/vascan/ [Accessed Dec. 7, 2010].

Burns, R.M. and B.H. Honkala (tech. coords.). 1990. Silvics of North America: 1. Conifers; 2. Hardwoods. USDA For. Serv., Washington, DC. Agric. Handb. No. 654. 877 p.

Burton, P.J., C. Messier, D.W. Smith and W.L. Adamowicz (eds.). 2003. Towards sustainable management of the boreal forest. NRC Research Press, Ottawa. 1039 p.

Buse, L.J. and F.W. Bell. 1992. Critical silvics of selected crop and competitor species in northwestern Ontario. Ont. Min. Nat. Resour., Northw. Ont. For. Technol. Develop. Unit, Thunder Bay, ON. 134 p. Campbell, D.R., L. Rochefort and C. Lavoie. 2003. Determining the immigration potential of plants colonizing disturbed environments: the case of milled peatlands in Québec. J. Appl. Ecol. 40(1): 78-91.

Cavers, P. B. and G.A. Mulligan. 1972. A new series - the biology of Canadian weeds. Can. J. Plant Sci. 52(4): 651-654.

Chapin, F.S., P.A. Mattson and H.A. Mooney. 2002. Principles of Terrestrial Ecosystem Ecology. Springer, New York.

Christensen, N.L. et al. 1996. The Report of the Ecological Society of America Committee on the Scientific Basis for Ecosystem Management. Ecol. Appl. 6(3): 665-691.

Coates, D., S. Haeussler and J. Mather. 1990. A guide to the response of common plants in British Columbia to management treatments. B.C. Min. For., Res. Br., Victoria, BC. FRDA Handb. 008 Coladonato, M. 1994. Rubus canadensis. In Fire Effects Information System. USDA For. Serv., Rocky Mtn. Res. Sta., Fire Sci. Lab. (Producer) [online]. Available at http://www.fs.fed.us/database/feis/ [Accessed October 29, 2010].
Conn, J.S. and M.L. Farris. 1987. Seed viability and dormancy of 17 weed species after 21 months in Alaska. Weed Sci. 35(4): 524-529.

Connell, J.H. 1980. Diversity and the coevolution of competitors, or the ghost of competition past. Oikos 35(2): 131-138.

Díaz, S. and M. Cabido. 2001. Vive la différence: plant functional diversity matters to ecosystem processes. TRENDS Ecol. Evol. 16(11): 646-655.

Dirr, M. 1990. Manual of woody landscape plants their identification ornamental characteristics, culture, propagation and uses. Stipes Publishing, Champaign, IL. 1007 p.

Farmer, R.E. 1997. Seed Ecophysiology of Temperate and Boreal Zone Forest Trees. St. Lucie Press, Delray Beach, FL. 253 p.

Gibson, D. 1961. Life-Forms of Kentucky Flowering Plants. Am. Midl. Nat. 66(1): 1-60.

Gilliam, F.S. 2007. The ecological significance of the herbaceous layer in temperate forest ecosystems. BioScience 57(10): 845-858.

Grime, J.P. 1998. Benefits of plant diversity to ecosystems: Immediate, filter and founder effects. J. Ecol. 86(6): 902-910.

Haeussler, S. and D. Coates. 1986. Autecological characteristics of selected species that compete with conifers in British Columbia: A literature review. B.C. Min. For., Victoria, BC. FRDA Rep. No. 1.180 p. Haeussler, S., D. Coates and J. Mather. 1990. Autecology of common plants in British Columbia: A literature review. B.C. Min. For., Victoria, BC. FRDA Rep. No. 158. 272 p.

Harrington, C.A. 1984. Factors influencing initial sprouting of red alder. Can. J. For. Res. 14(3): 357-361.

Harris, H.T. 1990. Populus balsamifera subsp. balsamifera. In Fire Effects Information System. USDA For. Serv., Rocky Mtn. Res. Sta., Fire Sci. Lab. (Producer) [online]. Available at http://www.fs.fed.us/ database/feis/ [Accessed October 27, 2010].

Howard, J.L. 1993. Oplopanax horridus. In Fire Effects Information System. USDA For. Serv., Rocky Mtn. Res. Sta., Fire Sci. Lab. (Producer) [online]. Available at http://www.fs.fed.us/database/feis/ [Accessed October 29, 2010].

Jobidon, R. 1995. Autécologie de quelques espèces de compétition d'importance pour la régénération forestière au Québec. Revue de littérature. Min. Res. Nat. QC., Dir. Rech. For., Sainte-Foy, QC. Mém. Rech. For. 117. 180 p.

Jobidon, R. 1997. Stump height effects on sprouting of mountain maple, paper birch and pin cherry-10 year results. For. Chron. 73(5): 590-595.

Kirchner, O., E. Loew and C. Schröter. 1908-1936. Lebensgeschichte der Blütenpflanzen Mitteleuropas. Ulmer, Stuttgart. Klapp, E. 1965. Grünlandvegetation und Standort. Berlin.

Kleyer M. et al. 2008. The LEDA Traitbase: a database of life-history traits of the Northwest European flora. J. Ecol. 96(6): 1266-1274.

Klimešová J. and L. Klimeš. 2008. Clonal growth diversity and bud banks in the Czech flora: an evaluation using the CLO-PLA3 database. Preslia 80: 255-275.

Klinka, K., V.J. Krajina, A. Ceska and A.M. Scagel. 1989. Indicator Plants of Coastal British Columbia. UBC Press, Vancouver, BC.

Klotz, S., I. Kühn and W. Durka. (eds.) 2002. BIOLFLOR Eine Datenbank zu biologisch-ökologischen Merkmalen der Gefäßpflanzen in Deutschland. Schriftenreihe für Vegetationskunde 38: 1-334.

Knevel, I.C., R.M. Beker, J.P. Bakker and M. Kleyer. 2003. Life-history traits of the NW European flora: The LEDA database. J. Veg. Sci.14(4): 611-614.

Kramer, N.B. and F.D. Johnson. 1987. Mature forest seed banks of three habitat types in central Idaho. Can. J. Bot. 65(9): 1961-1966. Lavorel, S., S. McIntyre, J.J. Landsberg and T.D.A. Forbes. 1997. Plant functional classifications: from general groups to specific groups based on response to disturbance. Trends Ecol. Evol. 12(12): 474-478.

Louter, J.H., M. Kershaw and A.M. Gordon. 1993. The autecology of competing non-crop vegetation on old field sites in southern Ontario. Ont. Min. Nat. Resour., Sci. Technol. Transf. Unit (Southern Region), Brockville, ON. 143 p. 
Mallik, A.U. 1993. Ecology of a forest weed of Newfoundland: vegetative regeneration strategy of Kalmia angustifolia. Can. J. Bot. 71(1): 161-166.

Marks, P.L. 1974. The role of pin cherry (Prunus pensylvanica L.) in the maintenance of stability in northern hardwood ecosystems. Ecol. Monogr. 44:73-88.

Matthews, R.F. 1992. Alnus viridis subsp. crispa. In Fire Effects Information System. USDA For. Serv., Rocky Mtn. Res. Sta., Fire Sci. Lab (Producer) [online]. Available at http://www.fs.fed.us/database/ feis/ [Accessed November 15, 2010].

McLaren, B., L. Hermanutz, J. Gosse, B. Collet and C. Kasimos. 2009. Broadleaf competition interferes with balsam fir regeneration following experimental removal of moose. For. Ecol. Manage. 257(5): 1395-1404.

McKenney, D.W., M.F. Hutchinson, J.L. Kesteven and L.A.Venier. 2001. Canada's plant hardiness zones revisited using modern climate interpolation techniques. Can. J. Plant Sci. 81(1): 129-143.

Mihail, J.D., J.N. Bruhn, T.R. Meyer and F.W. Bell. 2002. Pine needle rust effect on Pinus banksiana in response to interspecific plant competition and telial host density. Can. J. For. Res. 32(8): 1372-1380. Newmaster, S.G. and R. Subramanyam. 2005. Flora Ontario Integrated Botanical Information System (FOIBIS), Phase I. University of Guelph, Canada (online). Available at http://www.uoguelph. ca/foibis/ [Accessed Oct. 27, 2010].

Newton, M. 1973. Forest rehabilitation in North America: some simplifications. J. For. 71(3): 159-162.

Nilsson, M.-C. and D.A. Wardle. 2005. Understory vegetation as a forest ecosystem driver: evidence from the northern Swedish boreal forest. Frontiers Ecol. Environ. 3(8): 421-428.

Noste, N.V., E.D. Reinhardt and R.A.Wilson, Jr. 1987. Fire effects on Amelanchier alnifolia shrubs during phenological development stages. Paper presented at Symposium on Shrub Ecophysiology and Biotechnology. June 30 - July 2, 1987. Logan, UT. 6 p.

Paula, P. et al. 2009. Fire-related traits for plant species of the Mediterranean Basin. Ecology 90(5): 1420.

Paula, S. and J.G. Pausas. 2008. BROT: a plant trait database for Mediterranean Basin species. Version 2008.03 [online]. Available at http://www.uv.es/jgpausas/brot.htm.

Pausas, J.G., R.A. Bradstock, D.A. Keith, J.E. Keeley and the GCTE (Global Change of Terrestrial Ecosystems) Fire Network. 2004. Plant functional traits in relation to fire in crown-fire ecosystems. Ecology 85(4):1085-1100.

Pausas, J.G. and M. Verdu. 2005. Plant persistence traits in fireprone ecosystems of the Mediterranean basin: a phylogenetic approach. Oikos 109(1): 196-202.

Poschlod, P., M. Kleyer, A.-K. Jackel, A. Dannemann and O. Tackenberg. 2003. BIOPOP - A Database of plant traits and internet application for nature conservation. Folia Geobot. 38(3): 263-271.

Poschlod P., M. Kleyer and O. Tackenberg. 2000. Databases on life history traits as a tool for risk assessment in plant species. Z. Ökologie Nat. 9(1): 3-18.

Poschlod, P. D. Matthies, S. Jordan and C. Mengel. 1996. The biological flora of Central Europe - an ecological bibliography. Bull. Geobot. Inst. ETH 62: 89-108.

Posner, S. and P. Jordan. 2002. Competitive effects on plantation white spruce saplings from shrubs that are important browse for moose. For. Sci. 48(2): 283-289.

Puettmann, K.J, K.D. Coates and C. Messier. 2008. A Critique of Silviculture: Managing for Complexity. Island Press, Wash. DC. 208 p.

Rabotnov, T.A. (ed.). 1974. Biologičeskaja flora Moskovskoj oblasti. Izdatelstvo Moskovskogo Universiteta, Moscou.

Radosevich, S.R., J.S. Holt and C.M. Ghersa. 2007. Ecology of Weeds and Invasive Plants: Relationships to Agriculture and Natural Resource Management, $3^{\text {rd }}$ ed. Wiley \& Sons, Inc., Hoboken, NJ. 454 p.

Ramovs, B.V. and M.R. Roberts. 2005. Response of plant functional groups within plantations and naturally regenerated forests in southern New Brunswick, Canada. Can. J. For. Res. 35(6): $1261-1276$.
Rice, E.L. 1984. Allelopathy, $2^{\text {nd }}$ ed. Academic Press, Orlando, FL. Roberts, M.R. 2004. Response of the herbaceous layer to natural disturbance in North American forests. Can. J. Bot. 82(9): 1273-1283.

Royal Botanic Gardens Kew. 2008. Seed Information Database (SID). Version 7.1 [online]. Available at http://data.kew.org/sid/ Schopmeyer, C.S. (tech. coord.). 1974. Seeds of Woody Plants in the United States. USDA For. Serv., Washington, DC. Agric. Handb. No. 450.

Simard, S.W. and D.M. Durall. 2004. Mycorrhizal networks: a review of their extent, function, and importance. Can. J. Bot. 82(8): 1140-1165.

Sims, R.A., H.M. Kershaw and G.M. Wickware. 1990. The autecology of major tree species in the North Central Region of Ontario. For. Can., Ontario Reg., Great Lakes For. Cent, COFRDA Report 3302/ NW Ont. For. Tech. Devel. Unit, Ont. Min. Nat. Resour., Thunder Bay, ON. NWOFTDU Tech. Rep. 120 p.

Steinberg, P.D. 2001. Populus balsamifera subsp. trichocarpa. In Fire Effects Information System. USDA For. Serv., Rocky Mtn. Res. Sta., Fire Sci. Lab. (Producer) [online]. Available at http://www.fs.fed.us/ database/feis/ [Accessed October 27, 2010].

Thiffault, N., B.D. Titus and A.D. Munson. 2004. Black spruce seedlings in a Kalmia-Vaccinium association: microsite manipulation to explore interactions in the field. Can. J. For. Res. 34(8): 1657-1668.

Tirmenstein, D. 1999. Juniperus communis. In Fire Effects Information System. USDA For. Serv., Rocky Mtn. Res. Sta., Fire Sci. Lab. (Producer) [online]. Available at http://www.fs.fed.us/database/feis/ [Accessed October 28, 2010].

Tollefson, J.E. 2007. Betula nana. In Fire Effects Information System. USDA For. Serv., Rocky Mtn. Res. Sta., Fire Sci. Lab. (Producer) [online]. Available at http://www.fs.fed.us/database/feis/ [Accessed October 28, 2010].

Trindle, J.D.C and T.R. Flessner. 2003. Propagation protocol for production of container Valeriana sitchensis Bong. plants (1-year containers ); USDA NRCS - Corvallis Plant Materials Center, Corvallis, OR In Native Plant Network. University of Idaho, College of Natural Resources, Forest Research Nursery, Moscow, ID [online]. Available at http://www.nativeplantnetwork.org [Accessed 6 January 2010].

Uchytil, R.J. 1989. Alnus viridis subsp. sinuata. In Fire Effects Information System. USDA For. Serv., Rocky Mtn. Res. Sta., Fire Sci. Lab (Producer) [online]. Available at http://www.fs.fed.us/database/feis/ [Accessed October 28, 2010].

[USDA] United States Department of Agriculture. 1948. WoodyPlant Seed Manual. USDA For. Serv., Washington, DC. Misc. Publ. $654.416 \mathrm{p}$.

Venier, L. and S. Holmes. 2010. A review of the interaction between forest birds and eastern spruce budworm. Environ. Rev. 18: 191-207. Violle, C., M.-L. Navas, D. Vile, E. Kazakou, C. Fortunel, I. Hummel and E. Garnier. 2007. Let the concept of trait be functional! Oikos 116(5): 882-892.

Wagner, R.G. 1994. Toward integrated forest vegetation management. J. For. 92(11): 26-30.

Wagner R.G., F.W. Bell and R.A. Campbell. 2001. Vegetation management. In R.G. Wagner and S.J. Colombo (eds.). Regenerating the Canadian Forest - Principles and Practice for Ontario. pp. 431-458. Fitzhenry \& Whiteside Limited, Markham, ON.

Wagner, R.G. and J.C. Zasada. 1991. Integrating plant autecology and silvicultural activities to prevent forest vegetation management problems. For. Chron. 67(5): 506-513.

Walkup, C.J. 1991. Shepherdia canadensis. In Fire Effects Information System, [Online]. USDA For. Serv., Rocky Mtn. Res. Sta., Fire Sci. Lab. (Producer) [online]. Available at http://www.fs.fed.us/database/feis/ [Accessed October 29, 2010].

Walstad, J.D. and P.J. Kuch. 1987. Introduction to forest vegetation management. In J.D. Walstad and P.J. Kuch (eds.). Forest Vegetation Management for Conifer Production. pp. 3-14. John Wiley \& Sons, New York. 
Wiensczyk, A., K.I. Swift, A. Morneault, N. Thiffault, K. Szuba and F.W. Bell. 2011. An overview of the efficacy of vegetation management alternatives for conifer regeneration in boreal forests. For Chron. 87(2): 175-200.

Wright, I.J. et al. 2004. The worldwide leaf economics spectrum. Nature 428(6985): 821-827.

Young, J.A. and C.G. Young. 1992. Seeds of Woody Plants in North America. Dioscorides Press, Portland, OR. 407 p.

Zasada, J.C. 1971. Natural regeneration of interior Alaska forests seed, seedbed and vegetative reproduction considerations. In C.W. Slaughter, R.J. Barney and G.M. Hansen (eds.). Fire in the Northern Environment - A Symposium. pp. 231-246. USDA For. Serv., Pac. Northw. For. Range Exp. Sta., Portland, OR.
Zasada, J.C. 1988. Reproductive biology of trees and shrubs in interior Alaska. In E. Hamilton and S. Watts (comps.). Vegetation Competition and Responses: Proc. Third Annual Vegetation Management Workshop. pp. 78-79. B.C. Min. For. Lands, Vancouver, BC. FRDA Rep. 026. 85 p.

Zouhar, K. 2001. Cirsium arvense. In Fire Effects Information System. USDA For. Serv., Rocky Mtn. Res. Sta., Fire Sci. Lab. (Producer) [online]. Available at http://www.fs.fed.us/database/feis/ [Accessed November 17, 2010]. 